\author{
Л.М. Джума, О.М. Дмітрієв, О.С. Лавриненко, М.Ю. Сорока
}

Льотна академія Національного авіаційного університету, Кропивницький

\title{
МЕТОД ВИЛУЧЕННЯ ЗНАНЬ ПРО ПРОФЕСІЙНУ ДІЯЛЬНІСТЬ ДИСПЕТЧЕРА АЕРОДРОМНОЇ ДИСПЕТЧЕРСЬКОЇ ВИШКИ 3 ВИКОРИСТАННЯМ КОМБІНОВАНОГО МЕТОДА ХРОНОМЕТРАЖУ
}

\begin{abstract}
У статті увага зосереджується на декомпозииії процесу прийняття рішень диспетчером аеродромної диспетчерської вишки й детальному виявленні більш розширеного переліку технологічних операцій, необхідного й достатнього для реалізачії еталонної моделі суб'єкта навчання інтелектуальної навчальної системи “Диспетчер Tower". Реалізація даної моделі стає можливою завдяки обтрунтованому поєднанню різних методів, щзо дозволяє розвивати (удосконалити) існуючі методи видобування знань про предметну область. Запропоновано підхід з використанням так званого комбінованого методу хронометражу, наведено результати його застосування.
\end{abstract}

Ключові слова: диспетчер аеродромної диспетчерської вишки (АДВ), методи видобування знань, інтелектуальна навчальна система, комбінований метод хронометражу, дотренажерна самостійна підготовка, уніфікація, еталонна модель суб'єкта навчання.

\section{Вступ}

Постановка проблеми. Сучасні тенденції підготовки висококваліфікованих фахівців практично в усіх сферах людської діяльності та в авіаційній, зокрема, здебільшого зводяться до самостійної роботи суб'єкта навчання. Інтелектуальна навчальна система “Диспетчер Tower”, що розробляється на кафедрі інформаційних технологій Льотної академії НАУ, націлена забезпечити таку можливість при підготовці диспетчера аеродромної диспетчерської вишки (АДВ)

В основу інтелектуальних навчальних систем закладаються еталонна й поточна моделі суб'єкта навчання, які в процесі функціонування системи тісно взаємодіють. Створення еталонної моделі суб'єкта навчання стає можливим за наявності необхідного й достатнього інформаційного масиву, що відображає закономірності в професійній діяльності диспетчера АДВ.

У структурі розроблюваного методу побудови еталонної моделі суб'єкта навчання центральне місце займає етап збору даних та вилучення знань. Даний етап передбачає отримання найбільш повного 3 можливих уявлень про предметну область і способи прийняття рішення в ній [1, С. 53]. На цьому етапі проводиться змістовний аналіз проблемної області, виявляються використовувані поняття, їхні взаємозв'язки, визначаються різні методи вирішення завдань, такі як вивчення документації, що регламентує професійну діяльність людини оператора; анкетування / інтерв'ювання діючих операторів; хронометраж професійної діяльності людини-оператора. Для отримання більш детального опису діяльності людини оператора пропонується використання комбінованого метода хронометражу, що передбачає застосування двох різних підходів, які називаються, відповідно до класифікації Г. Архангельського [2]:

- хронометраж з використанням контрольнозаписуючої апаратури (метод диктофона, магнітофона);

- хронометраж способом безпосереднього спостереження з відеозаписом робочого процесу або самостійного спостереження (так званий паперовий метод).

Також на даному етапі ефективно використовувати методи вилучення знань [1, С. 53] такі, як аналіз літератури, діалоги з експертами, експертні ігри, лекції, дискусії та інше.

Аналіз останніх досліджень і публікацій. Використання еталонних моделей на даний момент, в основному, розглядається під час розробки інтелектуальних систем загального дидактичного навчання та являють собою набір референтних значень, так званих еталонних множин [3], для визначення компетентності того, хто навчається. У роботах [3-4] пропонується здійснювати витяг еталонних множин 3 державного освітнього стандарту про вищу освіту. В роботі [5] еталонна модель системи будується на отриманих знаннях від експерта в процесі взаємодії 3 нею, тим самим формуючи й перебираючи безліч рішень. Еталонні моделі, що формуються для автоматизованих систем навчання операторів, висвітлені в роботах [6-7], в основному являють собою набір / перелік алгоритмів дій у конкретних штатних та позаштатних ситуаціях, описаних у виробничій документації. Застосування зазначених вище підходів до вилучення знань та, як наслідок, формування еталонних моделей, є прийнятним і можливим лише для добре документованих та структурованих предметних областей, які не належать до складних без- 
перервно-дискретних стохастичних динамічних систем зі змішаною структурою.

Мета статті - опис методу вилучення знань про професійну діяльність диспетчера аеродромної диспетчерської вишки як добре документованої та середньо структурованої предметної області з використанням комбінованого метода хронометражу.

\section{Виклад основного матеріалу}

\section{Аналіз професійної діяльності диспетчера АДВ і виявлення загального переліку технологічних операцій}

Процес вилучення знань про предметну область передбачає взаємодію інженера по знаннях та експерта у формі безпосереднього живого спілкування. Дана форма здобування знань $є$ поширеною, але не єдиною. На рис. 1 представлено класифікацію методів вилучення знань 3 найбільш уживаною термінологією, де в залежності від конкретного завдання передбачається відповідний метод вилучення знань.

3 цієї класифікації видно, що основний принцип поділу пов'язаний з джерелом знань.

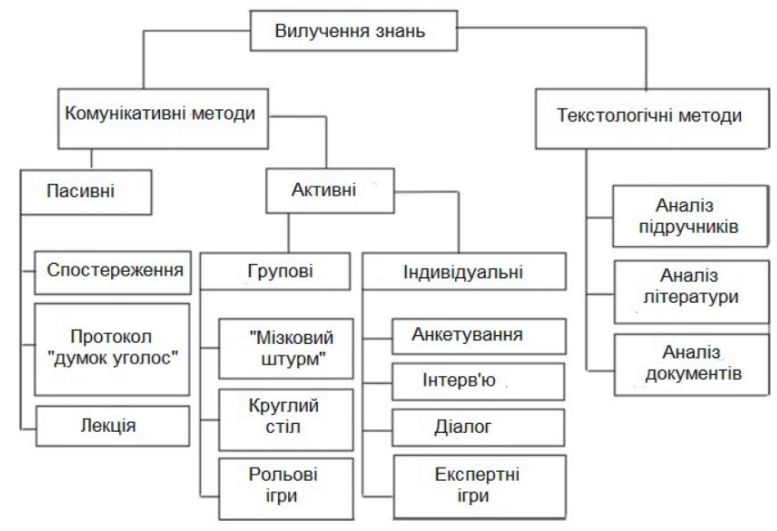

Рис. 1. Класифікація методів вилучення знань Джерело: [1, С. 100].

Комунікативні методи вилучення знань охоплюють методи та процедури контактів інженера по знаннях з безпосереднім джерелом знань - експертом, а текстологічні включають методи здобуття знань 3 документів (методик, посібників, керівництв) і спеціальної літератури (статей, монографій, підручників).

Поділ цих методів на верхньому рівні класифікації не означає їх антагоністичності, часто інженер по знаннях комбінує різні методи, наприклад, спочатку вивчає літературу, потім розмовляє $з$ експертами або навпаки.

Комунікативні методи, в свою чергу, можна також розділити на дві групи: активні й пасивні. Пасивні методи передбачають надання експерту провідної ролі в процедурі отримання, а інженер по знаннях тільки записує протокол міркувань експерта під час його реальної роботи по прийняттю рішень або фіксує всю необхідну інформацію. В активних методах, навпаки, ініціатива знаходиться повністю в руках інженера по знаннях, який різними способами активно контактує з експертом: в іграх, діалогах, бесідах за круглим столом і т.д.

Пасивні методи на перший погляд досить прості, але насправді вимагають від інженера по знаннях чітко аналізувати потік свідомості експерта і виявляти в ньому значущі фрагменти знань. Відсутність зворотного зв'язку (пасивність інженера по знаннях) значно послаблює ефективність цих методів, чим і пояснюється їх допоміжна роль при використанні активних методів.

Активні методи можна розділити на дві групи в залежності від числа експертів, які віддають свої знання. Якщо їх число більше одного, то доцільно, крім серії контактів 3 кожним, застосовувати також методи групових обговорень предметної області. Такі групові методи зазвичай активізують мислення учасників дискусії і дозволяють виявляти в достатній мірі нетривіальні аспекти їхніх знань. У свою чергу індивідуальні методи на сьогоднішній день залишаються провідними [1, С. 102].

На вибір методу впливають три чинники: особистісні особливості інженера по знаннях, особистісні особливості експерта й характеристика предметної області.

Для характеристики предметних областей використовують таку класифікацію [1, С.101]:

- добре документовані;

- середньо документовані;

- слабко документовані.

Крім цього, предметні області можна розділити за критерієм структурованості знань. Під структурованістю слід розуміти ступінь теоретичного осмислення й виявлення основних закономірностей та принципів, що діють у даній області.

За ступенем структурованості знань предметні області можуть бути [1, С. 102]:

- добре структурованими - 3 чіткою аксіоматизацією, широким застосуванням математичного апарату, усталеною термінологією;

- середньо структурованими - 3 визначеною термінологією, з теорією, що розвивається, явними взаємозв'язками між явищами;

- слабко структурованими - 3 розмитими визначеннями, багатою емпірикою, прихованими зв'язками.

Вилучення знань різними методами нами проводилося в трьох службах обслуговування повітряного руху - Запоріжжі, Одесі та Дніпрі. За основу предметної області взято професійну діяльність авіаційного диспетчера на робочому місці аеродромної диспетчерської вишки (АДВ) Запорізької служби обслуговування повітряного руху (ЗСОПР) у 
зв'язку з можливістю проведення найбільш повного обсягу досліджень, а також із наступних причин:

- аеродром ЗСОПР відноситься до контрольованого аеродрому, тому диспетчер АДВ виконує свої функції в повному обсязі;

- інтенсивність повітряного руху на даному аеродромі варіюється, що дозволяє проаналізувати роботу авіадиспетчера при різному ступені навантаження;

- схема аеродрому наближена до типової - на аеродромі є одна (робоча) штучна злітно-посадкова смуга (ЗПС), що є характерним для більшості аеродромів України;

- документи, що регламентують професійну діяльність диспетчера управління повітряним рухом (УПР) АДВ ЗСОВД, відповідають загальним державним та європейським вимогам, які пред'являються до даного авіаційного фахівця.

Основні функціональні обов'язки диспетчера аеродромної диспетчерської вишки ЗСОВД описані в робочій інструкції, а також в інструкції з виконання польотів [8-9] і мають таке представлення (на прикладі видачі диспетчером дозволу на посадку повітряного судна) [8, С. 51-52]:

1. Диспетчер АДВ видає дозвіл на посадку, коли існує обгрунтована впевненість в тому, що на момент перетину повітряним судном порогу ЗПС буде забезпечуватися ешелонування, і на ЗПС відсутні будь-які перешкоди, які можуть створити небезпеку для повітряного судна (ПС), що прибуває.

2. Дозвіл на посадку видається з ініціативи диспетчера. Диспетчеру не слід вимагати від екіпажу ПС надання доповідей про готовність до посадки або випуску шасі.

3. Дозвіл на посадку або будь-який альтернативний дозвіл повинний, як правило, передаватися на борт ПС до того, як воно досягне відстані, що дорівнює 4 км від точки приземлення.

У будь-якому випадку для забезпечення встановлених часових інтервалів, при наявності (очікуванні) іншого ПС на ЗПС, диспетчер повинен заздалегідь надати екіпажу ПС, що виконує заходження на посадку, вказівку про доповідь прольоту дальнього приводного радіомаяка (ДПРМ). При одержанні доповіді про проліт ДПРМ диспетчер повинен:

- якщо ПС знаходиться на виконавчому старті й не почало зліт - заборонити зліт і надати вказівку екіпажу ПС, що виконує заходження на посадку, про вихід на друге коло;

- якщо ПС ще не звільнило ЗПС після посадки - надати екіпажу ПС, що виконує заходження на посадку, вказівку про вихід на друге коло.

4. Дозвіл на посадку має включати:

- інформацію про місцевий рух (у разі потреби);
- інформацію про умови на аеродромі (у разі потреби);

- спеціальні вказівки (у разі потреби);

- напрямок і швидкість вітру;

- дозвіл на посадку.

5. Із дозволом на посадку обов'язково має бути зазначена ЗПС, яка використовується для посадки.

Збірник аеронавігаційної інформації України (AIP України) являє собою збірник відомостей, який включає в себе довгострокову аеронавігаційну інформацію, що має важливе значення для аеронавігації [10].

Збірники аеронавігаційної інформації містять [11, C. 5.2-5.3]:

- назву компетентного органу, відповідального за аеронавігаційні засоби, обслуговування або процедури, відомості про яких містяться в АIP;

- загальні умови надання обслуговування або засобів для міжнародного використання;

- перелік істотних відмінностей між національними правилами й практикою держави і відповідними Стандартами, Рекомендованою практикою й Правилами Міжнародної організації цивільної авіації (ІКАО) у такій формі, яка дозволила б користувачу швидко встановлювати відмінності між вимогами держави та відповідними вимогами IКАО;

- вказівку на вибір, зроблений державою в кожному важливому випадку, коли Стандартами, рекомендованою практикою й Правилами IКАО передбачається альтернативний варіант дій.

Найбільше значення для диспетчера являють аеронавігаційні карти й схеми, які входять до складу AIP. Карти і схеми в графічному, а також формальному вигляді описують особливості конкретного аеродрому, та вимагають завантаження в базу даних навчальної системи, що розробляється. Карти бувають [12]:

- карта аеродрому / вертодрому;

- карта наземного аеродромного руху;

- карта аеродромних перешкод, тип А;

- карта аеродромних перешкод, тип В;

- карта місцевості й перешкод в районі аеродрому;

- карта стоянки / постановки на стоянку повітряного судна;

- карта району;

- оглядова карта мінімальних абсолютних висот УПР;

- карта заходу на посадку за приладами;

- карта місцевості для точного заходу на посадку;

- карта стандартного прибуття за приладами;

- карта стандартного вильоту за приладами;

- карта візуального заходу на посадку.

Інтерв'ювання, а також подальше анкетування діючих диспетчерів АДВ із різним досвідом роботи 
Запорізької та Одеської служб обслуговування повітряного руху (ОПР) дозволили сформувати основний перелік технологічних операцій на різних етапах прийняття рішень диспетчером АДВ, а також отримати попередню оцінку часу, що витрачається на виконання цих операцій. При використанні методу інтерв'ювання діючі диспетчери описували алгоритм своїх дій і вказували приблизний час, який вони витрачають на їхнє виконання.

При використанні методу анкетування від диспетчерів вимагалося вказати час, що витрачається на виконання технологічних операцій (ТО), зазначених у переліку, сформованому на основі інтерв'ювання, порядку виконання ТО при обслуговуванні ПС, що виконують заходження на посадку. В результаті отримано зведену табл. 1 переліку технологічних операцій.

В табл. 1 використано наступні скорочення та позначення:

- технологічна операція (ТО);

- мінімальний та максимальний час виконання ТО одеськими спеціалістами;

- мінімальний і максимальний час виконання ТО запорізькими фахівцями;

- мінімальний і максимальний час виконання ТО за результатами анкетування; а також підтвердити або спростувати правильність

- час (Min, Max), сформований на підставі попередніх досліджень (інтерв'ювання та анкетування);

- сформований порядок виконання ТО;

- джерело інформації - кому або від кого диспетчер АДВ передає / отримує інформацію.

Результати вивчення документації, яка регламентує професійну діяльність диспетчера АДВ, проведеного інтерв'ювання та анкетування дозволяють зробити висновок, що розглядувана нами предметна область $є$ добре документованою й середньо структурованою.

Дані, отримані на основі інтерв'ювання та анкетування, не дозволяють надати технологічний процес у достатньому обсязі для формування адекватної еталонної моделі суб'єкта навчання. При цьому, отриманий результат дозволяє реалізувати свого роду підготовчий етап для проведення хронометраж⿻:

- вивчення технології виконання роботи, трудового процесу відповідно до інструкції та фактичного виконання;

- декомпозиція досліджуваної діяльності на складові елементи;

- визначення чітких меж складових елементів - фіксованих точок;

- формування спостережного листка - хронологічної карти.

Таблиця 1

Перелік технологічних операцій, отриманих на підставі інтерв'ювання та анкетування діючих диспетчерів

\begin{tabular}{|c|c|c|c|c|c|c|c|c|}
\hline \multirow{2}{*}{$\begin{array}{c}\text { № } \\
\text { 3/II }\end{array}$} & \multirow[t]{2}{*}{ Технологічна операція } & \multirow[b]{2}{*}{ 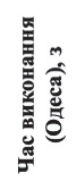 } & \multirow[b]{2}{*}{ 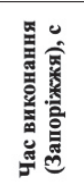 } & \multirow[b]{2}{*}{ 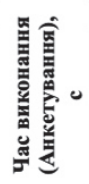 } & \multirow[b]{2}{*}{ 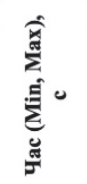 } & \multirow[b]{2}{*}{ 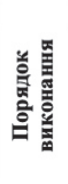 } & \multicolumn{2}{|c|}{ Джерело інформації } \\
\hline & & & & & & & від кого & кому \\
\hline 1 & Отримати інформації про виліт рейсу & $5-30$ & $15-40$ & $5-30$ & 5,40 & 1 & $\begin{array}{l}\text { Диспетчер Руління/ } \\
\text { ARO } \\
\end{array}$ & \\
\hline 2 & Підтвердити інформацію про виліт рейсу & & $5-40$ & $10-40$ & 5,40 & 2 & & Диспетчер Руління \\
\hline 3 & Отримати інформацію від Підходу про прибуття рейсу & & $10-20$ & $10-20$ & 10,20 & 3 & Диспетчер Підходу & \\
\hline 4 & Підтвердити інформацію диспетчеру Підходу & & $10-20$ & $10-15$ & 10,20 & 4 & & Диспетчер Підходу \\
\hline 5 & $\begin{array}{l}\text { Отримати доповідь від екіпажу ПС про місцезнаходження на } \\
\text { посадкової прямий і готовності до посадки }\end{array}$ & 30 & $5-15$ & $5-25$ & 5,30 & 5 & Екіпаж ПС & \\
\hline 6 & $\begin{array}{l}\text { Переконатися, що ЗПС вільна або виконуеться процедура } \\
\text { звільннння ЗПС }\end{array}$ & $10-300$ & $15-180$ & $15-120$ & 10,300 & 6 & & \\
\hline 7 & Видати дозвіл на посадку & 10 & 15 & $10-15$ & 10,15 & 7 & & Екіпаж ПС \\
\hline 8 & Отримати підтвердження дозволу на посадку від екіпажу ВС & & 10 & $5-10$ & 5,10 & 8 & Екіпаж ПС & \\
\hline 9 & Візуальний контроль руху ПС до торкання з ЗПС і пробігу по ЗПС & & $180-600$ & $250-300$ & 180,600 & 9 & & \\
\hline 10 & Отримати доповідь від екіпажу ПС "Посадку произвел" & & 10 & $5-10$ & 5,10 & 10 & Екіпаж ПС & \\
\hline 11 & Видати інструкцію екіпажу щодо маршруту звільнення зПС & & $5-20$ & $10-15$ & 5,20 & 11 & Екіпаж ПС & \\
\hline 12 & $\begin{array}{l}\text { Отримати підтвердження інструкцій від екіпажу ПС про маршрут } \\
\text { звільнення зПС }\end{array}$ & & $5-10$ & 3-10 & 2,10 & 12 & & Екіпаж ПС \\
\hline 13 & $\begin{array}{l}\text { Передати Рулінню інформацію про зарулювання ПС після посадки } \\
\text { (Номер рейсу і номер РД) }\end{array}$ & 10 & & $5-10$ & 5,10 & 13 & Диспетчер Руління & \\
\hline 14 & $\begin{array}{l}\text { Отримати підтвердження від Руління про прийняття інформації } \\
\text { про зарулювання ПС після посадки }\end{array}$ & 10 & & 5-10 & 5,10 & 14 & & Диспетчер Руління \\
\hline 15 & Передати інформацію в ARO про посадку & & $10-20$ & $5-15$ & 5,20 & 15 & & Диспетчер ARO \\
\hline 16 & Отримати підтвердження від ARO про посадку & & $10-20$ & $5-15$ & 5,20 & 16 & Диспетчер ARO & \\
\hline 17 & Отримати інформацію від екіпажу ПС про звільнення ЗПС & & $5-10$ & $2-5$ & 2,10 & 17 & Екіпаж ПС & \\
\hline 18 & Візуально проконтролювати звільнення ЗПС & & 5 & $5-100$ & 5,20 & 18 & & \\
\hline 19 & Перевести екіпаж ПС на зв'язок з Рулінням & 10 & & $5-10$ & 5,10 & 19 & Екіпаж ПС & \\
\hline 20 & Отримати підтвердження від екіпажу ПС про роботу з Рулінням & 10 & & $2-10$ & 2,10 & 20 & & Екіпаж ПС \\
\hline 21 & Зробити запис в журналі обліку & & $30-60$ & $30-45$ & 30,60 & 21 & & \\
\hline 22 & Інформувати екіпаж ПС про зміну тиску QNH & & $5-10$ & $5-10$ & 5,10 & $05-10$ & & Екіпаж ПС \\
\hline 23 & Отримати підтвердження від екіпажу ПС про зміну QNH & 5 & 4 & $2-5$ & 2,5 & $08-10$ & Екіпаж ПС & \\
\hline 24 & Отримання інформації від Метеослужби про зміну QNH & & 10 & $5-10$ & 5,10 & $1-21$ & & Метеослужба \\
\hline 25 & Підтвердження інформації Метеослужбі про зміну тиску QNH & & 10 & $3-10$ & 3,10 & 24 & Метеослужба & \\
\hline
\end{tabular}

Джерело: розроблено авторами. 


\section{Деталізація й уніфікація технологічних \\ операцій диспетчера АДВ за допомогою використання даних комбінованого хронометражу}

Вивчення предметної області, а також комунікативні та текстологічні методи вилучення знань показали, що для виконання своїх функцій авіадиспетчер використовує в роботі радіотехнічні засоби навігації, радіозв'язок з екіпажами ПС, засоби телефонного та гучномовного зв'язку для координації, консультацій та ефективного обміну інформацією, з такими службами [1, С. 102-130; 13, С. 28-31]:

- диспетчерським пунктом руління;

- диспетчерським органом підходу;

- сектором польотно-інформаційного обслуговування;

- керівником польотів;

- аеродромною службою;

- метеорологічною службою;

- інженером служби радіотехнічного забезпечення;

- службою електро-світлотехнічного забезпечення.

Координація та взаємодія з іншими службами є важливими елементами системи, які забезпечують безпеку польотів. Для забезпечення взаємодії з вищевказаними службами та екіпажами ПС диспетчер оперує мовними повідомленнями (командами, доповідями). Щоб уточнити перелік технологічних операцій, отриманий на попередньому етапі (табл. 1) визначити час їхнього виконання, нами був обраний метод хронометражу діяльності диспетчера АДВ.

Хронометраж-метод дослідження результативних показників трудових дій (зокрема в процесі їхнього освоєння): виміри відрізків часу на виконання окремих дій з метою визначення оптимального часу, норм праці (зокрема учнівських норм часу на різних періодах виробничого навчання), темпу роботи, ритму праці, оцінки ступеня тренованості учнів [14, С. 245]. Цей метод дозволяє визначити тривалість дій та операцій, тривалість пауз між окремими операціями.

Проведення хронометражу робочого процесу складається з наступних етапів [15, С. 107-118]:

1. Підготовчий: ознайомлення 3 робочим місцем і діяльністю. До проведення хронометражу на робочому місці повинні бути усунені всі організаційно-технічні несправності.

2. Спостереження: визначаються показники поточного часу за приладами й заносяться в хронологічну карту, а також фіксуються всі перерви та різні відхилення.

3. Обробка й аналіз результатів спостережень - робота над отриманими даними.

Нами визначено підготовчий етап проведення хронометражу діяльності диспетчера АДВ, що вмі- щує вивчення документації, яка регламентує професійну діяльність, аналіз його робочого місця, вивчення робочої інструкції, інструкції з виконання польотів на аеродромі. Інтерв'ювання та анкетування операційного персоналу з обслуговування повітряного рух дозволили отримати попередній перелік технологічних операцій при управлінні повітряним рухом (хронологічну карту).

Eman спостереження (безпосереднього хронометражу) розділений нами на дві складові - розшифрування магнітофонних даних запису радіообміну диспетчера АДВ, а також безпосереднє спостереження за його діяльністю на робочому місці.

Перша складова - хронометраж $з$ використанням контрольно-записуючої апаратури проводився на робочому місці диспетчера АДВ (TWR/DE2) Запорізького аеродромного диспетчерського центру (АДЦ) Дніпровського регіонального структурного підрозділу Державного підприємства обслуговування повітряного руху. Таким чином зібрано й розшифровано 63 години 40 хвилин магнітофонних (диктофонних) записів за період квітень - вересень 2015 року.

Проведений хронометраж діяльності диспетчера АДВ при управлінні ПС, які прибувають, а також iз координації авіадиспетчера з іншими службами, дозволив провести декомпозицію його обов'язків, описаних в робочій інструкції (табл. 2).

Друга складова - хронометраж з безпосереднім спостереженням (паперовий метод) за професійною діяльністю на робочому місці диспетчера АДВ Дніпровського регіонального структурного підрозділу (РСП) Державного підприємства обслуговування повітряного руху (TWR/DD1). Визначення технологічних операцій диспетчера АДВ в процесі управління ПС на етапі посадки здійснювалося на основі матеріалу, зібраного за травень 2015 року.

В ході вивчення Робочої інструкції диспетчера аеродромної диспетчерської вишки Дніпра й візуального спостереження за його діяльністю в процесі виконання ним УПР на етапі посадки були виділені 27 технологічних операцій, частина 3 яких представляє собою сукупність дій (табл. 3).

Слід зазначити, що отримані технологічні операції були виявлені за наступних умов:

- прості метеорологічні умови;

- льотне поле придатне до виконання польотів;

- роботи на льотній смузі й в критичних зонах дії курсового радіомаяка (КРМ) та глиссадного радіомаяка (ГРМ) не відбувались;

- у всіх розглянутих випадках екіпаж ПС (EBC) виконують інструментальний захід на посадку за правилами польотів за приладами (ППП);

- інтенсивність руху мінімальна;

- процедура прийому чергування диспетчером АДВ завершена. 
Декомпозиція обов'язків диспетчера АДВ ЗСОПР на технологічні операції (на підставі хронометражу з використанням контрольно-записуючої апаратури)

\begin{tabular}{|c|c|}
\hline $\begin{array}{c}\text { Обов'язки диспетчера АДВ при управлінні } \\
\text { повітряним рухом відповідно до робочої } \\
\text { інструкції }\end{array}$ & $\begin{array}{c}\text { Технологічні операції, виявлені на підставі } \\
\text { хронометражу операторської діяльності } \\
\text { диспетчера АДВ }\end{array}$ \\
\hline \multicolumn{2}{|c|}{ При прильоті ПС диспетчер вишки зобов'язаний виконати такі технологічні операції } \\
\hline \multirow{4}{*}{$\begin{array}{l}\text { Отримати, підтвердити й записати в «Журнал реєстрації ПС» } \\
\text { інформацію про рух ПС від диспетчера пункту збору донесень } \\
\text { (ARO / Брифінг), яка включає: аеродром вильоту; номер (лі- } \\
\text { тер) рейсу; тип і реєстраційний номер ПС; час вильоту }\end{array}$} & Перший зв'язок з Брифінгом - виклик \\
\hline & Перший зв'язок з Брифінгом - відповідь \\
\hline & Отримання інформації про виліт з іншого аеродрому \\
\hline & Підтвердження інформації про виліт з іншого аеродрому \\
\hline Перевірити наявність плану в списку активних планів & Неможливо отримати дані при обробиі магнітофонних записів \\
\hline \multirow{5}{*}{$\begin{array}{l}\text { Отримати від центрального диспетчера аеропорту (ЦДА) } \\
\text { (ЦДА) місце стоянки та існуючі обмеження }\end{array}$} & Перший зв'язок із ЦДА - виклик \\
\hline & Перший зв'язок із ЦДА - відповідь \\
\hline & Запит стоянки для прибуваючого ПС \\
\hline & Отримання інформації про стоянку для прибуваючого ПС \\
\hline & Підтвердження інформації щодо стоянки \\
\hline $\begin{array}{l}\text { Повідомити відповідальному за супровід (у разі потреби): тип, } \\
\text { позивний ПС, місце стоянки і маршрут руління }\end{array}$ & $\begin{array}{l}\text { При розшифруванні даних хронометражу, подібних випадків не } \\
\text { спостерігалося }\end{array}$ \\
\hline \multicolumn{2}{|c|}{ До прольоту точки прийому контролю руху за ПС диспетчер АДВ повинен: } \\
\hline $\begin{array}{l}\text { Ознайомитися } 3 \text { метеоінформацією за допомогою засобів } \\
\text { відображення метеоданих. }\end{array}$ & Неможливо отримати дані при обробичі магнітофонних записів \\
\hline \multirow{3}{*}{$\begin{array}{l}\text { Отримати від диспетчера підходу інформації про рух ПС за } \\
\text { правилами польоту за приладами й запитуваний тип заходу на } \\
\text { посадку, а також номер (літер) рейсу або позивний ПС }\end{array}$} & Перший зв'язок з диспетчером Підходу - виклик \\
\hline & Перший зв'язок з диспетчером Підходу - відповідь \\
\hline & Отримання інформації щодо прибуваючого ПС \\
\hline $\begin{array}{l}\text { Підтвердити отримання інформації про рух ПС диспетчеру } \\
\text { підходу й зробити відповідну відмітку в журналі реєстрації } \\
\text { ПС }\end{array}$ & Підтвердження інформації щодо прибуваючого ПС \\
\hline \multicolumn{2}{|c|}{ Після виходу екіпажу ПС на зв'язок на сегменті кінцевого етапу заходу на посадку диспетчер вишки повинен: } \\
\hline & Одержання доповіді від екіпажу ПС про готовність до посадки \\
\hline $\begin{array}{l}\text { Інформувати екіпаж про видалення від точки приземлення } \\
\text { (у разі потреби) }\end{array}$ & $\begin{array}{l}\text { При розшифруванні даних хронометражу, подібних випадків не } \\
\text { спостерігалося }\end{array}$ \\
\hline $\begin{array}{l}\text { Переконатися, що ЗПС і смуги безпеки вільні й світлове табло } \\
\text { "ЗПС зайнята" вимкнено }\end{array}$ & Неможливо отримати дані при обробиі магнітофонних записів \\
\hline \multirow[b]{2}{*}{ Видати дозвіл на виконання посадки. } & Видача дозволу на виконання посадки \\
\hline & $\begin{array}{l}\text { Отримання підтвердження від екіпажу ПС дозволу на виконання } \\
\text { посадки }\end{array}$ \\
\hline \multicolumn{2}{|c|}{ Після посадки диспетчер АДВ повинен: } \\
\hline $\begin{array}{l}\text { Ввести ознаку «Посадка» у підсистему обробки планової } \\
\text { інформації АС КПР; }\end{array}$ & Неможливо отримати дані при обробиі магнітофонних записів \\
\hline \multirow{4}{*}{ Передати час посадки ПС диспетчеру ЦДА і ARO } & $\begin{array}{l}\text { Доповідь про посадку службам, запит у служб щодо готовності } \\
\text { записати уточнену інформацію }\end{array}$ \\
\hline & $\begin{array}{l}\text { Отримання підтвердження готовності служб прийняти уточнену } \\
\text { інформацію }\end{array}$ \\
\hline & Видача уточненої інформацію про посадку ПС \\
\hline & $\begin{array}{l}\text { Отримання підтвердження службами уточненою інформацією } \\
\text { про посадку ПС }\end{array}$ \\
\hline \multicolumn{2}{|c|}{ Інструкції щодо руління після посадки: } \\
\hline \multirow{4}{*}{$\begin{array}{l}\text { Після виконання посадки, диспетчер повинен видати екіпажу } \\
\text { ПС вказівку на звільнення ЗПС. В умовах низької видимості, } \\
\text { повітряному судну, яке виконує посадку або рулювання, може } \\
\text { бути дана вказівка доповісти про звільнення ЗПС після того, } \\
\text { як ПС повністю звільнить відповідне місце очікування біля } \\
\text { ЗПС. }\end{array}$} & $\begin{array}{l}\text { Одержання доповіді екіпажу ПС після посадки (обов'язково } \\
\text { тільки в умовах низької видимості) }\end{array}$ \\
\hline & Видача диспетчером інструкції на звільнення ЗПС \\
\hline & $\begin{array}{l}\text { Отримання підтвердження екіпажем ПС інструкції зі звільнення } \\
\text { ЗПС }\end{array}$ \\
\hline & Одержання доповіді від екіпажу ПС про звільнення ЗПС \\
\hline \multirow{2}{*}{$\begin{array}{l}\text { Після звільнення ПС ЗПС, видати екіпажу ПС вказівки щодо } \\
\text { руління до місця стоянки, а саме опис маршруту руління й } \\
\text { номер місця стоянки (передати важливу аеродромну інформа- } \\
\text { цію у разі потреби). }\end{array}$} & Видача екіпажу ПС інструкцій щодо зарулювання на стоянку \\
\hline & $\begin{array}{l}\text { Отримання підтвердження екіпажем ПС інструкції щодо зару- } \\
\text { лювання }\end{array}$ \\
\hline
\end{tabular}

Джерело: розроблено авторами. 
Перелік технологічних операцій, виявлених на робочому місці диспетчера АДВ Дніпровського РСП в процесі хронометражу (паперовий метод)

\begin{tabular}{|c|c|}
\hline № 3/II & Назва технологічної операції \\
\hline 1 & Виконання контролю за тим, що ЗПС вільна і світлове табло "ЗПС зайнята" вимкнено. \\
\hline 2 & $\begin{array}{l}\text { Отримання від сектора TMA Dnipropetrovsk інформації щодо ПС, що виконує заходження на посадку (в мовному фор- } \\
\text { маті) і додаткової інформації в спеціальному вікні «ARRIVAL» автоматизованої системи УПР. }\end{array}$ \\
\hline 3 & Підтвердження отриманої інформації від сектора TMA Dnipropetrovsk щодо ПС, що виконують заходження на посадку. \\
\hline 4 & Перевірка наявності плану по поточному рейсу у списку активних планів системи. \\
\hline 5 & Виконання контролю за тим, що ЗПС вільна. \\
\hline 6 & Отримання доповіді від екіпажу ПС, що виконує посадку. \\
\hline 7 & Видача дозволу на виконання посадки екіпажу ПС. \\
\hline 8 & Отримання підтвердження від екіпажу ПС щодо прийнятого дозволу на виконання посадки \\
\hline 9 & Моніторинг траєкторії польоту ПС на сегменті кінцевого етапу заходу на посадку до дальнього приводного радіомаяка \\
\hline 10 & Запит екіпажу ПС щодо видачі інформації про фактичні параметри приземного вітру. \\
\hline 11 & Видача інформації щодо фактичних параметрів приземного вітру при прольоті ПС ДПРМ (на вимогу екіпажу ПС). \\
\hline 12 & Отримання підтвердження екіпажом ПС про отриману інформацію про фактичні параметри приземного вітру. \\
\hline 13 & Виконання контролю за тим, що ЗПС вільна. \\
\hline 14 & $\begin{array}{l}\text { Моніторинг траєкторії польоту ПС на сегменті кінцевого етапу заходу на посадку від ДПРМ до фіксованої точки при- } \\
\text { землення. }\end{array}$ \\
\hline 15 & $\begin{array}{l}\text { Моніторинг траєкторії руху ПС від фіксованої точки приземлення до видачі вказівки екіпажу ПС про порядок звіль- } \\
\text { нення ЗПС після посадки. }\end{array}$ \\
\hline 16 & $\begin{array}{l}\text { Видача вказівки екіпажу ПС про порядок звільнення ЗПС після посадки (i, при необхідності, доповіді екіпажу ПС про } \\
\text { звільнення ЗПС). }\end{array}$ \\
\hline 17 & Отримання підтвердження екіпажом ПС про порядок звільнення ЗПС. \\
\hline 18 & Передача даних щодо посадки ПС виробничої службі аеропорту (ПДСА). \\
\hline 19 & Отримання підтвердження від виробничої службою аеропорту (ПДСА) даних щодо посадки ПС \\
\hline 20 & Передача даних про посадку ПС диспетчеру брифінгу (ARO / AIS). \\
\hline 21 & Отримання підтвердження від диспетчера брифінгу (ARO / AIS) даних про посадку ПС. \\
\hline 22 & $\begin{array}{l}\text { Контроль за рулінням ПС в процесі звільнення ЗПС до видачі вказівки про перехід на зв'язок з диспетчером Ground. } \\
\text { (Доповідь про звільнення ЗПС видається екіпажом ПС на вимогу диспетчера Tower). }\end{array}$ \\
\hline 23 & Видача вказівки екіпажу ПС про перехід на зв'язок з диспетчером Ground \\
\hline 24 & Отримання від екіпажу ПС підтвердження даних про перехід на зв'язок з диспетчером Ground \\
\hline 25 & $\begin{array}{l}\text { Отримання запиту від екіпажу ПС на видачу додаткової інформації щодо змінених значень метеорологічних елементів } \\
\text { (при необхідності, але до висоти прийняття рішення). }\end{array}$ \\
\hline 26 & $\begin{array}{l}\text { Видача додаткової інформації щодо змінених значень метеорологічних елементів (при необхідності, але до висоти } \\
\text { прийняття рішення). }\end{array}$ \\
\hline 27 & $\begin{array}{l}\text { Отримання підтвердження від екіпажу ПС про прийом додаткової інформації щодо змінених значень метеорологічних } \\
\text { елементів (при необхідності, але до висоти прийняття рішення). }\end{array}$ \\
\hline
\end{tabular}

Джерело: розроблено авторами.

Переліки технологічних операцій Запорізької та Дніпровської служб були проаналізовані, внаслідок чого були знайдені подібності та розбіжності. Розбіжності обумовлені наступними факторами:

1) диспетчер АДВ Запоріжжя поєднує роботу трьох диспетчерських пунктів, а саме:

- пункту з видачі дозволу на політ за маршрутом (Delivery);

- пункту руління (Ground);

- пункту вишки (Tower),

тоді як диспетчер Дніпровської вишки виконує безпосередньо тільки функції пункту вишки, а функції пунктів Delivery i Ground виконує диспетчер пункту руління;

2) при аналізі роботи диспетчера АДВ Запоріжжя був застосований хронометраж із використанням контрольно-записуючої апаратури, а на Дніпровській вишці проводився хронометраж способом безпосереднього спостереження.

Використання комбінованого методу хронометражу дозволило найбільш розгорнуто представити технологію роботи диспетчера АДВ.
У першому випадку хронометраж дав можливість визначити види й тривалість дій (операцій), тривалість пауз між окремими операціями, але при цьому, фіксованими $є$ тільки аферентні оператори (отримання й передача команд і т.д.).

У другому випадку при хронометражі способом безпосереднього спостереження отримані як аферентні, так і еферентні оператори (натискання кнопок, представлення команд і т.д.), але при цьому тимчасові показники операцій $є$ менш точними, ніж в першому випадку.

Результати виконаної роботи дозволили:

- отримати більш розширений перелік технологічних операцій диспетчера АДВ, достатній для реалізації поставленого завдання;

- уніфікувати технологічні операції діяльності диспетчера АДВ при зльоті, посадці і зльотіпосадці;

- запропонувати трирівневу деталізацію (декомпозицію) процедур, що виконуються авіадиспетчером, яка дозволяє найбільш цілісно описати алгоритм діяльності диспетчера АДВ (рис. 2). 
Фрагмент отриманої деталізації представлено на рис. 2, він складається з наступних елементів:

- білий прямокутник із суцільною лінією контуру - технологічні операції, що мають характер еферентного оператора, які були виявлені в Запорізькій службі ОПР;

- білий прямокутник із пунктирною лінією контуру - технологічні операції, що мають характер аферентного оператора, які були виявлені в Запорізькій службі ОПР;

- сірий прямокутник із суцільною лінією контуру - технологічні операції, що мають характер еферентної оператора, які були виявлені в Дніпровському РСП;

- сірий прямокутник із пунктирною лінією контуру - технологічні операції, що мають характер аферентного оператора, які були виявлені в Дніпровському РСП.

В отриманій деталізації крім технологічних операцій диспетчера АДВ також містяться операції пункту рулювання (Ground) та пункту видачі диспетчерських дозволів на політ за маршрутом (Delivery). Це обумовлюється наступними моментами:

- при отриманні / продовженні свідоцтва диспетчера УПР (студента-диспетчера) кандидат проходить перевірку на диспетчерському тренажері, де він виконує функції всіх трьох вищевказаних диспетчерських пунктів (ДП);

- диспетчер АДВ, згідно з робочими інструкціями, виконує функції всіх трьох ДП ОПР в пріоритетній більшості українських аеропортів;

- суб'єкт навчання при виконанні функціональних обов'язків ДП АДВ, ДП рулювання і ДП з видачі диспетчерського дозволу на політ за маршрутом, отримує більший обсяг знань і навичок, що робить його придатним як до роботи на АДВ з об'єднаними функціями трьох ДП, так і придатним до роботи на будь-якому з пунктів окремо.

Спираючись на результати проведеної роботи 3 використанням комбінованого методу хронометражу по виявленню, вимірюванню, узагальненню, уніфікації та систематизації інформації щодо технологічних операцій, що виконуються диспетчером на робочому місці АДВ, можна рекомендувати його як такий, що дозволяє виконати декомпозицію технологічних операцій, виділених на підставі робочої інструкції, до рівня елементарних (неподільних) операцій, іншими словами, найбільш повно деталізувати технологічні операції та отримати час їхнього виконання, i, як наслідок, виявити необхідні закономірності для реалізації адекватної еталонної моделі суб'єкта навчання.

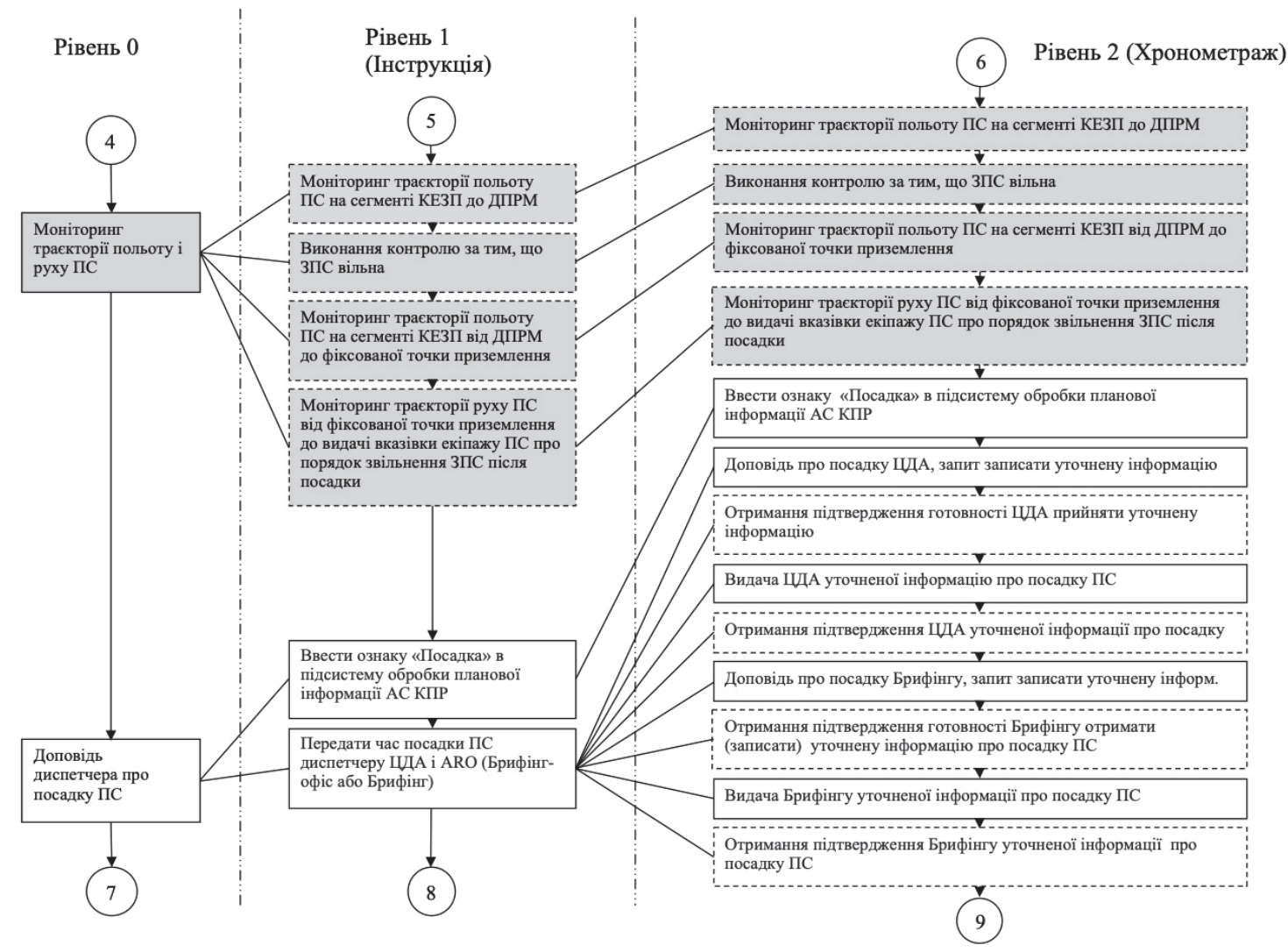

Рис. 2. Фрагмент трирівневої деталізації (декомпозиції) процедур, що виконуються авіадиспетчером АДВ Джерело: розроблено авторами. 


\section{Висновки}

В результаті проведених досліджень, які пройшли апробацію [16-17], запропоновано метод вилучення знань про професійну діяльність диспетчера аеродромної диспетчерської вишки як добре документованої і середньо структурованої предметної області, вдосконалений за рахунок використання комбінованого методу хронометражу діяльності людини-оператора. Запропонований метод дозволяє провести детальну до рівня елементарної операції декомпозицію досліджуваного нами процесу, отримати набори даних щодо часу виконання кожної 3 деталізованих технологічних операцій, виділити аферентні і еферентні оператори професійної діяльності диспетчера АДВ, тим самим провести структурний аналіз і надалі виконати синтез даної динамічної складної системи й процесів у ній.

\section{Список літератури} $384 \mathrm{c}$.

1. Гаврилова Т. А., Хорошевский В. Ф. Базы знаний интеллектуальных систем. Санкт-Петербург : Питер, 2000.

2. Тайм-менеджмент. Полный курс : монография / Г. Архангельский, М. Лукашенко, Т. Телегина, С. Бехтеров. Москва : Альпина Паблишер, 2012. 312 с.

3. Добрица В. П., Локтионова Н. Н. Применение теории нечетких множеств для оценки качества образованности обучающихся. Вестник РУДН. Серия: Информатизация образования. 2010. № 1. С. 66-71.

4. Хлопотов М. В. Применение байесовской сети при построении моделей для оценки уровня сформированности компетенций. Вестник евразийской науки. 2014. № 5(24). С. 36.

5. Сирота С. В., Таран Т. А. Обучение понятиям в интеллектуальных обучающих системах на основе формального концептуального анализа. Искусственный интеллект. Т. 3. 2000. С. 340-347.

6. Мигранова Э. А. Автоматизированная система отбора и обучения операторов для управления технологическими процессами : автореф. дис. ... канд. техн. наук : 05.13.07. Ташкент, 2011. 29 с.

7. Дозорцев В. М., Назин В. А., Баулин Е. С. О проблеме управления компетенциями операторов ТП в свете внедрения системы профессиональных стандартов. Автоматизация в промышленности. 2019. № 10. С. 48-55.

8. Запорізька служба ОПР Дніпропетровського РСП. Робоча інструкція аеродромної диспетчерської вишки Запоріжжя, 31.12.2013. $91 \mathrm{c}$.

9. Государственная служба Украины по надзору за обеспечением безопасности авиации. Инструкция по производству полетов аэродрома Запорожье. 2006 (2013). 30 с.

10. Про затвердження Положення про передпольотне інформаційне обслуговування на аеродромах цивільної авіації України : наказ Міністерства транспорту України від 25 червня 2003 р. № 458 URL: https://zakon.rada.gov.ua/ laws/show/z0573-03\#Техt (дата звернення: 14.12. 2020).

11. Приложение 15 к Конвенции о международной гражданской авиации “Службы аэронавигационной информации”. Издание 16, июль 2018. ИКАО.

12. Служба аеронавігаційної інформації Украіни. Аеронавігаційні публікації. еAIP: веб сайт. URL: http://www.aisukraine.net/publications/ukr/publ(ukr).htm (дата звернення: 10.12. 2020).

13. Піліпьонок О.М. Метод підвищення якості управління повітряними суднами операторами систем навігаційного обслуговування й управління рухом : дис. ... канд. техн. наук : 05.22.13. Кіровоградська льотна академія Національного авіаційного університету. Кропивницький, 2017. 265 с.

14. Вишнякова С. М. Профессиональное образование. Словарь. Ключевые понятия, термины, актуальная лексика. Москва : НМЦ СПО, 1999. 538 с.

15. Андросова Л. А. Экономика труда : учебное пособие. Пенза : Пенз. гос. ун-т, 2005. 160 с.

16. Джума Л. Н., Лавриненко А. С. Детализация технологических операций диспетчера АДВ с использованием метода хронометража. Управління високошвидкісними рухомими об' єктами та професійна підготовка операторів складних систем: матеріали IV Міжнародної науково-практичної конферениії. Кіровоград : КЛА НАУ, 26-27 листопада 2015. C.195-196. http://www.klanau.kr.ua/images/docs/mmnpk2627112015.pdf.

17. Джума Л. Н., Лавриненко А. С. Унификация технологических операций деятельности авиадиспетчера при разработке эталонной модели субъекта обучения. Авіація та космонавтика: стан, досягнення $і$ перспективи: матеріали ХХХVI Всеукраїнської науково-практичної конференції молодих учених та курсантів, яка присвячена Всесвітньому Дню авіації і космонавтики, Частина 1. м. Кіровоград: КЛА НАУ, 12 квітня 2016. С. 201-202. http://www.klanau.kr.ua/ images/docs/mvnpkxxxvip01.pdf.

\section{Відомості про авторів:}

Джума Людмила Миколаївна кандидат технічних наук доцент кафедри Льотної академії

Національного авіаційного університету, Кропивницький, Україна https://orcid.org/0000-0002-7043-3544

\section{Information about the authors:}

\section{Liudmyla Dzhuma}

Candidate of Technical Sciences

Senior Lecturer of Department

of Flight Academy of the National Aviation University,

Kropyvnytskyi, Ukraine

https://orcid.org/0000-0002-7043-3544 
Дмітрісв Олег Миколайович

доктор технічних наук доцент завідувач кафедри Льотної академії Національного авіаційного університету, Кропивницький, Україна https://orcid.org/0000-0003-1079-9744

\section{Лавриненко Олексій Сергійович} аспірант

диспетчер управління повітряним рухом

РСП “Київцентраеро” Украероруху,

Бориспіль, Україна

https://orcid.org/0000-0001-8783-3731

\section{Сорока Михайло Юрійович}

кандидат технічних наук

заступник начальника академії 3 навчальної науковометодичної та виховної роботи

Льотної академії

Національного авіаційного університету,

Кропивницький, Україна

https://orcid.org/0000-0003-1894-4002

\section{Oleh Dmitriiev}

Doctor of Technical Sciences Associate Professor

Head of Department

of Flight Academy of the National Aviation University,

Kropyvnytskyi, Ukraine

https://orcid.org/0000-0003-1079-9744

\author{
Oleksii Lavrynenko \\ Doctoral Student \\ Air traffic controller \\ of KYIVCENTRAERO UkSATSE, \\ Boryspil, Ukraine \\ https://orcid.org/0000-0001-8783-3731
}

\author{
Mykhailo Soroka \\ Candidate of Technical Sciences \\ Deputy Head of the Academy for Educational Scientific \\ and Methodological and Educational Work \\ of Flight Academy \\ of the National Aviation University, \\ Kropyvnytskyi, Ukraine \\ https://orcid.org/0000-0003-1894-4002
}

\title{
МЕТОД ИЗВЛЕЧЕНИЯ ЗНАНИЙ О ПРОФЕССИОНАЛЬНОЙ ДЕЯТЕЛЬНОСТИ ДИСПЕТЧЕРА АЭРОДРОМНОЙ ДИСПЕТЧЕРСКОЙ ВЫШКИ С ИСПОЛЬЗОВАНИЕМ КОМБИНИРОВАННОГО МЕТОДА ХРОНОМЕТРАЖА
}

\author{
Л.Н. Джума, О.Н. Дмитриев, А.С. Лавриненко, М.Ю. Сорока
}

В статье внимание фокусируется на предметной области, связанной с профессиональной подготовкой высококвалифицированных авиадиспетчеров, где на современном этапе, в силу стремительного развития информационных технологий, наблюдается тенденция внедрения самостоятельной составляющей в работе субъекта обучения; и - непосредственно с профессиональной деятельностью на рабочем месте диспетчера аэродромной диспетчерской вышки как объекта исследования.

Отмечается тот факт, что названная предметная область является спеиифичной и сложной, что требует 6 свою очередь особых подходов в процессе структурного анализа для ее детального изучения с иелью выявления всех свойств, закономерностей и дальнейшего синтеза динамической сложной системы, каковой является интеллектуальная обучающая система “Диспетчер Тошег”, разрабатываемая на кафедре информаџионных технологий Летной академии Национального авиационного университета. В основу подобных систем, как правило, закладываются эталонная и текущая модели субъекта обучения, которые тесно взаимодействуют между собой. Создание эталонной модели субъекта обучения становится возможным при наличии необходимого и достаточного информационного массива, отражающего закономерности в профессиональной деятельности диспетчера аэродромной диспетчерской вышки.

В прочессе проводимого научного исследования нами выявлено, что с точки зрения методов извлечения знаний о предметных областях, рассматриваемая область относится к хорошо документированным и средне структурированным. В процессе ее декомпозици существующие методы извлечения знаний в “классическом” виде не позволяют добиться достаточной детализачии для построения гибкой эталонной модели.

В статье основное внимание фокусируется на декомпозичии процесса принятия решений диспетчером аэродромной диспетчерской вышки и детальном выявлении более расширенного перечня технологических операций, необходимого и достаточного для реализации эталонной модели субъекта обучения интеллектуальной обучающей системы, указанной выше. Реализаџия данной модели становится возможной благодаря обоснованному сочетанию различных методов, позволяющему развивать (усовершенствовать) существующие методы извлечения знаний о предметной области.

В статье предложен подход с использованием так называемого комбинированного метода хронометража и приведены результаты его применения при извлечении знаний о профессиональной деятельности диспетчера аэродромной диспетчерской вышки как хорошо документированной и средне структурированной предметной области, что позволяет перейти к следующему этапу, связанному с формализацией и программной разработкой соответствующей эталонной модели.

Ключевые слова: диспетчер аэродромной диспетчерской вышки (АДВ), методы извлечения знаний, интеллектуальная обучающая система, комбинированный метод хронометража, предтренажерная самостоятельная подготовка, унификация, эталонная модель субъекта обучения. 
EXTRACTION OF KNOWLEDGE METHOD AS FOR THE PROFESSIONAL ACTIVITIES OF AN AIR TRAFFIC CONTROLLER OF AIRPORT TRAFFIC CONTROL TOWER USING THE COMBINED TIMING METHOD

\author{
L. Dzhuma, O. Dmitriiev, O. Lavrynenko, M. Soroka
}

The article focuses on the subject area related to the professional training of highly qualified air traffic controllers, where at the present stage, due to the rapid development of information technology, there is a tendency to introduce a self-paced training of the trainee; and directly professional activities in the workplace of the air traffic controller of airport traffic control tower (henceforth Tower Air Traffic Controller), as an object of research.

It is emphasized that the above subject area is specific and complex, which requires special approaches in the process of structural analysis for its detailed study to identify all properties, patterns and further synthesis of a dynamic complex system, like the intelligent training system "ATC of Tower", which is being developed by the Department of Information Technologies of the Flight Academy of the National Aviation University.

As a rule, such systems are based on the reference (or model-following) and current models of the trainee, which closely interact with each other. The reference model of the trainee creation becomes possible if there is a necessary and sufficient information array that reflects the patterns in the professional activity of Tower Air Traffic Controller.

In the course of the ongoing scientific research, we revealed that the area under consideration belongs to the welldocumented and medium-structured from the point of view of the method of subject area extracting knowledge. In the process of its decomposition, the existing methods of knowledge extraction in the "classical" form do not allow achieving sufficient detail to build a flexible reference model.

The article focuses on the decomposition of the Tower Air Traffic Controller decision-making process and the detailed identification of a more expanded list of technological operations which is necessary and sufficient for the implementation of the trainee reference model of the intelligent training system mentioned above. The implementation of this model becomes possible due to the reasonable combination of various methods, which makes it possible to develop (to improve) the existing methods of extracting knowledge related to the subject area.

The article proposes the approach using the so-called combined timing method and presents the results of its application when extracting knowledge about the professional activity of a Tower Air Traffic Controller as a well-documented and mediumstructured subject area, which allows one to proceed to the next stage associated with formalising and software development of the corresponding reference models.

Keywords: Air traffic controller of airport traffic control tower, knowledge extraction method, intelligent training system, combined timing method, pre-training self-training, unification, trainee reference model. 